\title{
ENVIRONMENTAL DISCLOSURE IN THE ANNUAL REPORTS OF THE JORDANIAN MINING AND EXTRACTION COMPANIES
}

\author{
DOI: 10.17261/Pressacademia.2018.787 \\ JEFA- V.5-ISS.1-2018(9)-p.100-107
}

\author{
Abdul Hakim Mustafa Joudeh ${ }^{1}$, Haitham I. M. Almubaideen ${ }^{2}$, Shaher Falah Alroud ${ }^{3}$ \\ ${ }^{1}$ Al-Isra University, Accounting Department, Faculty of Business, 11622, Amman, Jordan. \\ dr.hakim67@yahoo.com, ORCID:0000-0003-1143-4798 \\ 2 Al-Isra University, Accounting Department, Faculty of Business, 11622, Amman, Jordan. \\ halmubaideen@gmail.com, ORCID: 0000-0002-8684-1411 \\ 3 Al-Isra University, Accounting Department, Faculty of Business, 11622, Amman, Jordan. \\ shsa89@yahoo.com, ORCID: 0000-0001-6279-8650
}

\section{To cite this document}

Joudeh, A.H.M., Almubaideen, H.I.M., Alroud, S.F., (2018). Environmental disclosure in the annual reports of the Jordanian mining and extraction companies. Journal of Economics, Finance and Accounting (JEFA), V.5(1) p.100-107.

Permemant link to this document: http://doi.org/10.17261/Pressacademia.2018.787

Copyright: Published by PressAcademia and limited licenced re-use rights only.

\section{ABSTRACT}

Purpose - This study tries to evaluate the status of environmental disclosure in the financial reports of the Jordanian mining and extraction listed shareholding companies. In addition, the study focuses on identifying the barriers, which are facing these companies.

Methodology - Thus, to attain the aim of this study, the needed data have been collected through using a questionnaire as well as a set of secondary data, which are available in the annual reports of the study's sample.

Findings - As a result, the study showed that though all companies are presenting the environmental disclosure technique in their annual reports, however, the usage of this technique is uneven between the companies.

Conclusion - The study concluded that the Jordanian industrial companies do not pay attention to the forms of environmental disclosure.

Keywords: Environmental disclosure, annual reports, environmental disclosure problems, Jordanian mining and extraction companies. JEL Codes: M41, L61, Q56

\section{INTRODUCTION}

Since the environment has got the priority for countries, many countries have established ministries and high authorities to preserve their environments. Globally, various bodies, associations and organizations have been established to preserve the environment; such as, Greenpeace, friends of the environment societies or the Friends of Earth, which carries out important activities to highlight this important subject. Anyway, the interest in the environment has become a critical demand in most countries, as it is a global trend resulting in the emergence of environmental accounting due to its importance in providing information relates to environmental costs to assist the management in planning and control. Many governmental and non-governmental organizations are interested in exploring the environmental impacts of companies in their annual reports (Abdul Hussain, 2014, 292).

Relative studies indicated the increasing number of companies, which include environmental disclosure in their annual reports to meet the desires of investors and the other users of annual reports. The evidence on that is the increase in the content of disclosure of environmental information from mere a paragraph in the annual report to the preparation of independent environmental information reports, which are published by companies. Such disclosure appears in many forms; such as the descriptive data, quantitative facts, numbers and notes in the financial statements (Darwish, 2009; Suttipun \& Stanton, 2012; Jariya, 2015).

The early eighties of the $20^{\text {th }}$ century have witnessed the real beginning of the official interest in the environment in Jordan, when the Government decided to create a department of environmental connected with the Ministry of Municipality and Rural Affairs. Hence, Jordan started to focus on environmental planning and management due to the development of official conviction that the protection of environment is a part of the developmental area, which must be taken into consideration to reach to environmental balance that allows progress and growth. In addition, the protection and 
preservation of the environment is an essential requirement to ensure a sustainable development. Therefore, in Jordan there are many administrative and technical bodies were established, to care about environment. The Ministry of Environment in Jordan is deemed as the competent authority in the protection of the environment (Environmental Protection Law, 2006).

The environmental disclosure is a method by which companies could inform the society, with all its spectra, on their various activities concerning the environmental content. The annual reports are deemed an appropriate tool to achieve that. Today, the environmental disclosure in the annual reports of industrial companies is seen as one of the most important subjects. Thus, due to this importance, this study examines the level of environmental disclosure in the annual reports of the companies for the period 2016, as well as identifying the problems that impede the mining and extraction companies in Jordan from the environmental disclosure in their annual reports. To attain the aim of this study, the paper is including five sections. The first section includes the introductory, the study's problem, the study's objectives and the study's hypotheses. in the second section the study discusses the previous related studies as well as the definition of the environmental disclosure. Section number three explains the methodology of this study. The fourth section discussing the study findings and the fifth section presents the conclusion and recommendation of this study.

The subject of the environmental disclosure in the annual reports of the Jordanian industrial companies is still at the early stages. Additionally, the studies in this area are relatively few. Therefore, it is imperative to conduct further researches that could contribute to maximize the use of the annual reports and expanding the areas of disclosure. Thus, this study seeks to identify the problems that prevent the companies from presenting an environmental disclosure in their annual reports. To attain that the study copes with answering the following two questions:

1. Do the Jordanian mining and extraction companies present the environmental disclosure in their annual reports?

2. What are the problems that impede the Jordanian mining and extraction companies from presenting the environmental disclosure in their annual reports?

Today, the environmental disclosure in the annual reports is found as one of the most important and up-to-date subjects because the companies are no longer aimed to realize profits only, but to avoid some aspects that harm the community and damaging the environment. Therefore, the purpose of this study is to provide an appropriate scientific contribution, through exploring the level of the environmental disclosure in the annual reports as well as identifying the external and internal problems of the environmental disclosure in the annual reports of the Jordanian mining and extraction companies during the 2016 .

This study aims to achieve the following two objectives:

1. Examining the level of environmental disclosure in the annual reports of the Jordanian mining and extraction companies.

2. Identifyingthe external and internal environmental disclosure problems in the annual reports of Jordanian mining and extraction companies.

The study is based on the following two hypotheses:

$\mathbf{H}_{01}$ : The Jordanian mining and extraction companies don't present the environmental disclosure in their annual reports.

$\mathbf{H}_{02}$ : There are no external and internal problems would prevent the Jordanian mining and extraction companies from presenting the environmental disclosure in their annual reports.

\section{LITERATURE REVIEW}

For the purpose of this study, the researchers revised some previous studies, which are relevant to the subject of this study. A study of Welbeck, at el. (2017) examined the type of environment-related information firms disclose mostly in Ghana, and investigate the determinants of environmental disclosures by firms in Ghana. Using the Global Reporting Initiative (GRI) index as a benchmark, a content analysis of the corporate annual report of (17) firms listed on the Ghana Stock Exchange (GSE) was conducted over a 10-year period (2003 to 2012) to determine the total environmental disclosure scores of the sampled firms. The determinants of environmental disclosure practices of the firms were ascertained by means of a regression analysis. The results indicated that the listed firms in Ghana disclose some amount of environmentally-related information espoused by GRI though the level of disclosure is low. Also, the level of disclosure by environmentally-sensitive firms is higher than the less sensitive firms similar to existing studies. Moreover, the study finds firm size, auditor type, age of the firm and industry type to be significant predictors of firms' environmental disclosure practices. Mazahrih, at el. (2016) investigates the quality of environmental reporting information by the chemical industry in Jordan. The focus is on prescribed accounting principles and reporting practices. Content analysis is utilized to attain the study's aims. The study demonstrates the extent of environmental reporting in two companies' annual reports at both national and international 
levels. The environmental reporting performance is measured against the literature and international initiatives. The results showed some differences between the two levels with regard to the quality, content and profile disclosure. The main reason for such variation in reporting could be attributed to the voluntary nature of environmental disclosure. Anyway, in the absence of legislation regarding environmental disclosure, doubts remain about the likelihood of better quality reporting. Md, et al. (2014) focused on providing a critical examination for the practices of environmental disclosure as well as the disclosure's extent in the industries of Bangladesh. As a result, the study showed that around $69 \%$ of the studied industries do not including any environmental issue in their annual reports.

Eljayash (2015) aims to document the environmental disclosure practices in the Arab Spring countries, Egypt, Libya and Tunisia. These countries have been witnessed a change in governance systems as a result of massive popular revolutions in 2011 in what became known revolutions of the Arab Spring. These revolutions have been influenced on the political and legal systems and economic development of these countries. As a result, due of the accounting system interacts with surrounding systems; the changes of systems may affect the accounting system, thus accounting practices, including environmental disclosure practices that may be affected. Therefore, the researcher focused on documenting the environmental disclosure practices in the oil companies for the three years that preceded the Arab Spring revolution. As result, it will contribute in comparisons for the accounting practices of companies after the success of the Arab Spring uprisings. Content analysis and environmental disclosure index are used to measure the quantity and quality of environmental disclosure in companies operating in the oil sector. The results of the study indicated low accounting information contained in the annual reports before Arab spring.

Uzzaman and Kowsar (2014) present an empirical investigation into the corporate environmental reporting practices of a number of listed non-financial companies from Bangladesh. Based on both primary and secondary data, the study reveals that $(61.36 \%)$ of the listed companies have made such disclosures. Analysis over a wide range of industries reveals that companies in the pharmaceuticals and telecommunication sector secure the highest rank in terms of corporate environmental reporting; (88.90\%) of disclosures are generalized qualitative statements; $(96.30 \%)$ of CER is located in the director's report; and the mean amount of disclosures is less than one fourth of a page. The respondents have felt the strong need for CER in their Annual Reports, the respondents have also been aware of CER practices; the respondents have identified some major problems involved in CER and suggested some measures.

Yosuff, at el., (2013) investigate the state of environmental reporting by Malaysian and Australian companies on 'other' reports, i.e. other than annual reports. The paper employs content analysis to study the environmental disclosures made by the selected (100) companies in the two countries. Regression analysis is performed on potential influencing factors for environmental reporting. The paper finds that environmental reporting in 'other' reports (Malaysia and Australia) are largely descriptive and in qualitative form. In addition, the influencing factors for environmental reporting are of similar quality to those made in annual reports, in both countries. These findings imply that this type of communicating environmental information does not contribute greater corporate accountability among companies in fulfilling stakeholders' needs and demands for environmental information. Hence, more efforts are needed to promote better and greener environmental reporting practice. This study comparatively explored the environmental practices and interprets the possible link between the influencing factors for environmental reporting and actual environmental reporting practices on a two-country basis, between Malaysia and Australia. Bae and Kim (2018) studied the extent of using the environmental accounting as well as the environmental reporting in the banks of Bngaladesh. After analyzing data of tweenty banks, the results discovered that the banks of Bangladish tend to disclose the information, which are related to the categories of the renewable energy as well as the green banking.

The term 'environmental disclosure' is defined as the process through which the information was presented on the environmental obligations, which are resulting from a corporate daily activities. Although the concept of disclosure has one definition, whether environmentally or accounting, but it is noted that it is limited, in respect of accounting disclosure, to the presentation of the business results in the light of the accounting policies and concepts. It may not reflect the negative environmental effects resulting fromthe company's variousactivities. In such case, it results in shortage in the information presentation associated with the organization activities, in particular, the information related to the cost and environmental liabilities. This forms one of the challenges encountered by accounting recent years in which the industrial company's activities have increased and widened to include the negative effects resulting from dispensing toxic waste which is dangerous to the environment surrounding these companies (Al-Rashed, 2013, 11).

The environmental disclosure was also defined as "the presentation and provision of the data and information related to the environmental activities of the business facilities in the financial statements, which facilitates the work of the information users and decision-makers and lead to rationalize the decision in assessing the environmental performance of such companies" (Saleh, 2015, 89). 


\section{DATA AND METHODOLOGY}

This study has relied on the primary and secondary data. The primary data have been collected through the distribution of questionnaires by one questionnaire to the Heads of Finance Departments per company. The primary data was used to identify the external and internal problems of the environmental disclosure in the annual reports of the companies. The secondary data was collected through the annual reports of the companies for 2016 to examine the environmental disclosure level in the annual reports of these companies. This study is deemed an exploratory study (content study) and descriptive at the same time. The questionnaires were distributed to only 10 of the 16 companies of the year 2016, after taking their initial approval to distribute one questionnaire to each company. The total of the questionnaires delivered and collected were 10. All of them were analyzable.

\section{FINDINGS AND DISCUSSIONS}

\subsection{The environmental Disclosure in the Annual Reports}

One of the main objectives of this study is to examine the level of environmental disclosure in the annual reports of the Jordanian mining and extraction companies. Thus, through the examining the corporate annual reports on the level of environmental disclosure, the study noticed that the environmental disclosure forms in the annual reports focus on the qualitative disclosure, which is followed by the monetary and then the quantitative. This indicates that the companies of Jordan do not pay too much attention to the forms of the environmental disclosure in their annual reports, especially the quantitative disclosure. See the following Table 1.

Table 1: The Environmental Disclosure Forms

\begin{tabular}{|l|c|c|c|c|c|c|c|c|c|c|c|c|c|}
\hline \multirow{2}{*}{ Forms } & \multicolumn{9}{|c|}{ Companies } & \multirow{2}{*}{ Repetition } & \multirow{2}{*}{ \% } & Rank \\
\hline & $\mathbf{1}$ & $\mathbf{2}$ & $\mathbf{3}$ & $\mathbf{4}$ & $\mathbf{5}$ & $\mathbf{6}$ & $\mathbf{7}$ & $\mathbf{8}$ & $\mathbf{9}$ & $\mathbf{1 0}$ & & & \\
\hline Qualitative & $\checkmark$ & $\checkmark$ & $\checkmark$ & & $\checkmark$ & $\checkmark$ & $\checkmark$ & $\checkmark$ & $\checkmark$ & $\checkmark$ & 9 & $56 \%$ & 1 \\
\hline Monetary & $\checkmark$ & $\checkmark$ & $\checkmark$ & $\checkmark$ & $\checkmark$ & & & & $\checkmark$ & & 6 & $38 \%$ & 2 \\
\hline Quantitative & & $\checkmark$ & & & & & & & & & 1 & $65 \%$ & 3 \\
\hline \multicolumn{1}{|c|}{ Total } & & & & & & & & & & & $\mathbf{1 6}$ & $\mathbf{1 0 0 \%}$ & \\
\hline
\end{tabular}

The following table number 2 shows a significant weakness in the usage of the other forms of environmental disclosure, except the disclosure in the tables, which obtained $50 \%$ percent:

Table 2: Other Forms of the Environmental Disclosure

The following table shows other forms of the environmental disclosure in the annual reports:

\begin{tabular}{|c|c|c|c|c|c|c|c|c|c|c|c|c|c|}
\hline \multirow{2}{*}{ Forms } & \multicolumn{10}{|c|}{ Companies } & \multirow{2}{*}{ Repetition } & \multirow{2}{*}{$\%$} & \multirow{2}{*}{ Rank } \\
\hline & 1 & 2 & 3 & 4 & 5 & 6 & 7 & 8 & 9 & 10 & & & \\
\hline Image & & $\checkmark$ & & & & $\checkmark$ & & & & & 2 & $17 \%$ & 2 \\
\hline Map & & $\checkmark$ & & & & & & & & & 1 & $8 \%$ & 3 \\
\hline Table & $\checkmark$ & $\checkmark$ & $\checkmark$ & $\checkmark$ & $\checkmark$ & & & & $\checkmark$ & & 6 & $50 \%$ & 1 \\
\hline Diagram & $\checkmark$ & $\checkmark$ & & & & & & & & & 2 & $17 \%$ & 2 \\
\hline Comparison & & $\checkmark$ & & & & & & & & & 1 & $8 \%$ & 3 \\
\hline Total & & & & & & & & & & & 12 & $100 \%$ & \\
\hline
\end{tabular}

However, table number three demonstrates that the environmental disclosure was presented the Report of the Board of Directors (Board Report) and then in the financial statements, clarifications, and the company's mission. This indicates that most companies concentrate on the environmental disclosure in the Board report:

Table 3: The Environmental Disclosure Location

The following table shows the location of the environmental disclosure in the annual reports:

\begin{tabular}{|c|c|c|c|c|c|c|c|c|c|c|c|c|c|}
\hline \multirow{2}{*}{ Location } & \multicolumn{10}{|c|}{ Companies } & \multirow{2}{*}{ Repetition } & \multirow{2}{*}{$\%$} & \multirow{2}{*}{ Rank } \\
\hline & 1 & 2 & 3 & 4 & 5 & 6 & 7 & 8 & 9 & 10 & & & \\
\hline Company Mission & & & & & & $\checkmark$ & & & & & 1 & $5 \%$ & 4. \\
\hline Board Report & $\checkmark$ & $\checkmark$ & $\checkmark$ & & $\checkmark$ & $\checkmark$ & $\checkmark$ & $\checkmark$ & $\checkmark$ & $\checkmark$ & 9 & $47 \%$ & 1. \\
\hline Financial Statements & $\checkmark$ & $\checkmark$ & $\checkmark$ & $\checkmark$ & $\checkmark$ & & & & $\checkmark$ & & 6 & $32 \%$ & 2. \\
\hline Clarification & $\checkmark$ & $\checkmark$ & & & $\checkmark$ & & & & & & 3 & $16 \%$ & 3. \\
\hline Total & & & & & & & & & & & 19 & $100 \%$ & \\
\hline
\end{tabular}


The following table number four found that all companies showed the positive environmental disclosure, while ignored the negative disclosure, except one company revealed a negative environmental disclosure. Perhaps, this is because the conviction of the management that the negative disclosure may impact on the company's reputation:

\section{Table 4: Type of the Environmental News}

The following table shows the type of the environmental news in the annual reports:

\begin{tabular}{|c|c|c|c|c|c|c|c|c|c|c|c|c|c|}
\hline \multirow{2}{*}{ News } & \multicolumn{10}{|c|}{ Companies } & \multirow{2}{*}{ Repetition } & \multirow{2}{*}{$\%$} & \multirow{2}{*}{ Rank } \\
\hline & 1 & 2 & 3 & 4 & 5 & 6 & 7 & 8 & 9 & 10 & & & \\
\hline Positive & $\checkmark$ & $\checkmark$ & $\checkmark$ & $\checkmark$ & $\checkmark$ & $\checkmark$ & $\checkmark$ & $\checkmark$ & $\checkmark$ & $\checkmark$ & 8 & $89 \%$ & 1 \\
\hline Negative & & $\checkmark$ & & & & & & & & & 1 & $11 \%$ & 2 \\
\hline Total & & & & & & & & & & & 9 & $100 \%$ & \\
\hline
\end{tabular}

In table number five, it is found that the number of lines, which are allocated for the environmental disclosure in the annual reports of the companies wasless than ten lines, except two companies. The second company on average of 47 lines and the fifth company at average 13 lines. This indicates that the lines allocated for the environmental disclosure in annual reports werefew which does not exceed a quarter page:

Table 5: The number of lines allocated for the environmental disclosure

The following table shows the number of lines allocated for the environmental disclosure in the annual reports:

\begin{tabular}{|c|c|c|c|c|c|c|c|c|c|c|c|c|c|}
\hline \multirow[b]{2}{*}{ Lines } & \multicolumn{10}{|c|}{ Companies } & \multirow[b]{2}{*}{ Repetition } & \multirow{2}{*}{$\%$} & \multirow{2}{*}{ Rank. } \\
\hline & 1 & 2 & 3 & 4 & 5 & 6 & 7 & 8 & 9 & 10 & & & \\
\hline $1-5$ & $\checkmark$ & & & $\checkmark$ & & & $\checkmark$ & $\checkmark$ & $\checkmark$ & & 5 & $50 \%$ & 1 \\
\hline $6-10$ & & & $\checkmark$ & & & $\checkmark$ & & & & $\checkmark$ & 3 & $30 \%$ & 2 \\
\hline More than 10 & & $\checkmark$ & & & $\checkmark$ & & & & & & 2 & $20 \%$ & 3 \\
\hline Total & & & & & & & & & & & 10 & $100 \%$ & \\
\hline
\end{tabular}

Table number six describes that the environmental accounting disclosure component was ranked as the first, followed by the importance of environmental protection, and environmental health and safety in the second rank. The rest of the other elements were ranked third to seventh. The study also noted that the disclosure ratio is found weak, as it reached $25 \%$, the second company is the most disclosed by $25 \%$, followed by the fifth company by $19 \%$. It is also noted that by examining and analyzing the previous tables, from table (1) to (6), in general, all companies include an environmental disclosure in their annual reports, but poorly and unevenly. Based on the above, the null hypothesis stating that "the Jordanian mining and extraction companies do not present the environmental disclosure in their annual reports" was rejected:

\section{Table 6: Elements of the Environmental Disclosure}

The following table shows the elements of the environmental disclosure in the annual reports:

\begin{tabular}{|c|c|c|c|c|c|c|c|c|c|c|c|c|c|c|}
\hline \multirow{2}{*}{$\begin{array}{l}\text { Se } \\
\text { r. }\end{array}$} & \multirow{2}{*}{ The elements } & \multicolumn{10}{|c|}{ Companies } & \multirow{2}{*}{ Repetition } & \multirow{2}{*}{$\%$} & \multirow{2}{*}{$\begin{array}{l}\text { Ra } \\
\text { nk }\end{array}$} \\
\hline & & 1 & 2 & 3 & 4 & 5 & 6 & 7 & 8 & 9 & 10 & & & \\
\hline 1 & Environmental policy & & & & & & $\checkmark$ & & & & & 1 & $\begin{array}{c}10 \% \\
*\end{array}$ & 6 \\
\hline 2 & $\begin{array}{l}\text { Environmental } \\
\text { management }\end{array}$ & $\checkmark$ & $\checkmark$ & $\checkmark$ & & & & & & & & 3 & $30 \%$ & 4 \\
\hline 3 & Environmental events & & $\checkmark$ & & & & & & & & & 1 & $10 \%$ & 6 \\
\hline 4 & $\begin{array}{l}\text { Lawsuits on } \\
\text { environmental issues }\end{array}$ & & $\checkmark$ & & & & & & & & & 1 & $10 \%$ & 6 \\
\hline 5 & $\begin{array}{l}\text { Environmental } \\
\text { protection }\end{array}$ & & $\checkmark$ & & $\checkmark$ & $\checkmark$ & $\checkmark$ & & & $\checkmark$ & & 5 & $50 \%$ & 2 \\
\hline 6 & $\begin{array}{l}\text { Environmental } \\
\text { standards }\end{array}$ & & & & & $\checkmark$ & & $\checkmark$ & & & & 2 & $20 \%$ & 5 \\
\hline 7 & $\begin{array}{l}\text { Sustainable } \\
\text { development }\end{array}$ & & $\checkmark$ & & & $\checkmark$ & & & & & & 2 & $20 \%$ & 5 \\
\hline 8 & $\begin{array}{l}\text { Environmental } \\
\text { accounting }\end{array}$ & $\checkmark$ & $\checkmark$ & $\checkmark$ & $\checkmark$ & $\checkmark$ & $\checkmark$ & & & $\checkmark$ & & 7 & $70 \%$ & 1 \\
\hline 9 & $\begin{array}{l}\text { Environmental health } \\
\text { and safety }\end{array}$ & $\checkmark$ & $\checkmark$ & $\checkmark$ & & $\checkmark$ & $\checkmark$ & & & & & 5 & $50 \%$ & 2 \\
\hline 10 & Conservation of & & & & & $\checkmark$ & & & & & & 1 & $10 \%$ & 6 \\
\hline
\end{tabular}




\begin{tabular}{|c|c|c|c|c|c|c|c|c|c|c|c|c|c|c|}
\hline & natural resources & & & & & & & & & & & & & \\
\hline 11 & $\begin{array}{l}\text { Research and } \\
\text { development }\end{array}$ & & & & & $\checkmark$ & & & & & & 1 & $10 \%$ & 6 \\
\hline 12 & $\begin{array}{l}\text { Environmental } \\
\text { education and training }\end{array}$ & $\checkmark$ & $\checkmark$ & & & & $\checkmark$ & & & & $\checkmark$ & 4 & $40 \%$ & 3 \\
\hline 13 & Social interaction & & $\checkmark$ & & & & & & & & & 1 & $10 \%$ & 6 \\
\hline 14 & Environmental awards & & & $\checkmark$ & & & & & & & & 1 & $10 \%$ & 6 \\
\hline 15 & Treeplantation & & & & & $\checkmark$ & & & & $\checkmark$ & & 2 & $20 \%$ & 5 \\
\hline 16 & Soil & & $\checkmark$ & & & $\checkmark$ & & & & $\checkmark$ & & 3 & $30 \%$ & 4 \\
\hline 17 & Water management & & $\checkmark$ & $\checkmark$ & & & $\checkmark$ & & $\checkmark$ & & & 4 & $40 \%$ & 3 \\
\hline 18 & Solid waste & & & $\checkmark$ & & & & & $\checkmark$ & & & 2 & $20 \%$ & 5 \\
\hline 19 & Air pollution & & $\checkmark$ & & & & & $\checkmark$ & & & & 2 & $20 \%$ & 5 \\
\hline & Total & 4 & 12 & 6 & 2 & 9 & 6 & 2 & 2 & 4 & 1 & 48 & $\begin{array}{c}25 \% \\
* *\end{array}$ & - \\
\hline & Percentage \% & $\begin{array}{l}8 \% \\
* * *\end{array}$ & $25 \%$ & $13 \%$ & $4 \%$ & $19 \%$ & $13 \%$ & $4 \%$ & $4 \%$ & $8 \%$ & $2 \%$ & $100 \%$ & - & - \\
\hline
\end{tabular}

\subsection{The Problems of the Environmental Disclosure in the Annual Reports}

The second objective of this study is to identify the problems of environmental disclosure in the annual reports of the Jordanian mining and extraction companies. The problems of environmental disclosure in annual reports were divided into external problems and internal problems. As shown is table number seven, the results confirmed that the first paragraph is ranked as the first item that is followed by the paragraph number five. However, the second paragraph was considered as the least problem that is facing the Jordanian companies, while presenting the environmental disclosure in their annula reports. In general, the general scale of the arithmetic means of the external problems achieved was high, reached (3.85), with a standard deviation (0.659). This indicates an agreement of respondents that there are many external problems impede the environmental disclosure in companies:

\section{Table 7: External problems}

The following table shows the most important external problems:

\begin{tabular}{|c|c|c|c|c|c|}
\hline Ser. & Paragraph & $\begin{array}{c}\text { Arithmetic } \\
\text { mean }\end{array}$ & $\begin{array}{l}\text { Standard } \\
\text { deviation }\end{array}$ & $\begin{array}{c}\text { Relative } \\
\text { importance }\end{array}$ & Rank \\
\hline 1 & $\begin{array}{l}\text { The lack of legal and legislative texts that oblige the } \\
\text { environmental disclosure. }\end{array}$ & 4.06 & 0.907 & *High & 1 \\
\hline 2 & $\begin{array}{l}\text { Deficiency in many aspects in the environmental laws } \\
\text { and regulations. }\end{array}$ & 3.74 & 0.978 & High & 6 \\
\hline 3 & $\begin{array}{l}\text { Non-compliance with environmental laws and } \\
\text { regulations which obligate the disclosure. }\end{array}$ & 3.77 & 0.943 & High & 5 \\
\hline 4 & $\begin{array}{l}\text { Failure to take the legal procedures against } \\
\text { uncommitted companies to the instruction of } \\
\text { environmental disclosure. }\end{array}$ & 3.82 & 1.089 & High & 3 \\
\hline 5 & $\begin{array}{l}\text { The lack of governmental incentives and support to } \\
\text { the companies that comply with the environmental } \\
\text { disclosure. }\end{array}$ & 3.91 & 0.961 & High & 2 \\
\hline 6 & $\begin{array}{l}\text { Lack of local organizations that qualify professionals in } \\
\text { the field of environmental disclosure. }\end{array}$ & 3.80 & 0.878 & High & 4 \\
\hline \multicolumn{2}{|r|}{ General measure } & 3.85 & 0.659 & High & \\
\hline
\end{tabular}

However, after testing the hypotheses of this study, the results showed that the calculated value (T) is greater than the tabulated value (T), and the value of (alpha) is less than (0.05). Hence, we rejected the null hypothesis, which is stating that "There are no external problems would prevent the Jordanian mining and extraction companies from presenting the environmental disclosure in their annual reports". That means that there are external problems would prevent the Jordanian mining and extraction companies from presenting the environmental disclosure in their annual reports: 
Table 8: Results of testing the hypothesis

The following table shows the testing of hypothesis:

\begin{tabular}{|c|c|c|c|}
\hline T Calculated & T Tabulated & (Alpha) Sig & Result of the null hypothesis \\
\hline 5.61 & 2.13 & 0.00 & Rejected \\
\hline
\end{tabular}

The results also discovered that paragraph 5 in table number nine, stated that "Non-existence of a competent division for environmental disclosure" was ranked as the first), followed by paragraph No. 9, which is stating that "The difficulty of determining the costs of environmental disclosure" valued (3.79). While, the sixth paragraph, was ranked as the last with a value of 3.34. The general scale of the arithmetic means for the external problems was (3.57), with standard deviation (0.665). This indicates the respondents' agreement that the companies suffer internal problems impede the environmental disclosure:

\section{Table 9: The Internal Problems}

The following table shows the most important internal problems:

\begin{tabular}{|c|c|c|c|c|c|}
\hline Ser. & Paragraph & $\begin{array}{c}\text { Arithmetic } \\
\text { mean }\end{array}$ & $\begin{array}{l}\text { Standard } \\
\text { deviation }\end{array}$ & $\begin{array}{c}\text { Relative } \\
\text { importance }\end{array}$ & Rank \\
\hline 1 & $\begin{array}{l}\text { Lack of management awareness of the importance } \\
\text { of environmental disclosure. }\end{array}$ & 3.64 & 0.916 & Average & 4 \\
\hline 2 & $\begin{array}{l}\text { Lack of management attention to apply } \\
\text { environmental disclosure. }\end{array}$ & 3.60 & 1.039 & Average & 7 \\
\hline 3 & $\begin{array}{l}\text { Management believes that environmental } \\
\text { disclosure will negatively affect its reputation. }\end{array}$ & 3.42 & 1.002 & Average & 14 \\
\hline 4 & $\begin{array}{l}\text { The lack of internal instructions, regulations and, } \\
\text { rules relevant to the environmental disclosure. }\end{array}$ & 3.46 & 0.816 & Average & 12 \\
\hline 5 & $\begin{array}{l}\text { Non-existence of a competent division } \\
\text { forenvironmental disclosure. }\end{array}$ & 3.87 & 1.181 & High & 1 \\
\hline 6 & $\begin{array}{l}\text { The lack of accounting system that fulfils the } \\
\text { purposes of environmental disclosure }\end{array}$ & 3.34 & 1.010 & Average & 15 \\
\hline 7 & $\begin{array}{l}\text { Lack of full disclosure of information and } \\
\text { accounting policies related to environmental } \\
\text { disclosure. }\end{array}$ & 3.56 & 0.987 & Average & 8 \\
\hline 8 & $\begin{array}{l}\text { The high cost of applying the environmental } \\
\text { disclosure. }\end{array}$ & 3.54 & 1.005 & Average & 9 \\
\hline 9 & $\begin{array}{l}\text { The difficulty of determining the costs of } \\
\text { environmental disclosure. }\end{array}$ & 3.79 & 0.905 & High & 2 \\
\hline 10 & The absence of environmental auditing. & 3.51 & 0.806 & Average & 11 \\
\hline 11 & $\begin{array}{l}\text { Non-compliance with international accounting } \\
\text { standards or financial reporting standards for } \\
\text { environmental disclosure. }\end{array}$ & 3.43 & 0.910 & Average & 13 \\
\hline 12 & $\begin{array}{l}\text { Inadequate number of employees in the } \\
\text { Accounting Department to follow-up } \\
\text { environmental disclosure. }\end{array}$ & 3.53 & 0.880 & Average & 10 \\
\hline 13 & $\begin{array}{l}\text { The lack of sufficient scientific qualifications for } \\
\text { staff of the financial departments in relation to } \\
\text { environmental disclosure. }\end{array}$ & 3.61 & 1.117 & Average & 6 \\
\hline 14 & $\begin{array}{l}\text { The lack of adequate knowledge and skills of } \\
\text { Finance Departments staff with regard to the } \\
\text { environmental disclosure. }\end{array}$ & 3.65 & 0.971 & Average & 3 \\
\hline 15 & $\begin{array}{l}\text { The lack of educational programs and training } \\
\text { courses for the Finance Departments in relation to } \\
\text { the environmental disclosure. }\end{array}$ & 3.62 & 0.933 & Average & 5 \\
\hline \multicolumn{2}{|r|}{ General Scale } & 3.57 & 0.665 & Average & \\
\hline
\end{tabular}

Beyond that the results showed that the calculated value $(T)$ is greater than the tabulated value $(T)$ and the value of (alpha) is less than (0.05). Therefore, the study confirmed there are internal problems preventing the Jordanian mining and extraction companies from presenting the environmental disclosure in their annual reports: 


\section{Table 10: Results of testing the hypothesis}

The following table shows the testing hypothesis:

\begin{tabular}{|c|c|c|c|}
\hline T Calculated & T Tabulated & (Alpha) Sig. & Result of null hypothesis \\
\hline 9.72 & 2.13 & 0.00 & Rejected \\
\hline
\end{tabular}

\section{CONCLUSION AND RECOMMENDATIONS}

The study concluded that the Jordanian mining companies are not presenting the environmental disclosure in their annual reports properly. The Jordanian mining companies not only do not pay attention to the forms of the environmental disclosure, but also it is concentrated on presenting their disclosure in the board report. The Jordanian mining and extraction companies only focused on presenting the positive environmental disclosure. The ratio of the environmental disclosure elements is found to be weak. The study concluded that the Jordanian companies are encountering some problems, which are able to prevent the process of presenting the environmental disclosure properly.

Moreover, the study recommended that it is necessary to increase the attention to present the environmental disclosure in the annual reports of the Jordanian companies. The responsible parties must improve the regulations of applying the process of the environmental disclosure in the annual reports of the Jordanian mining and extracion companies. It is significant to manage the process of presenting the environmental disclosure through a team of qualified as well as skilled individuals. The study recommended that there is a necessacity to respect the rgulations of the environmental disclosure as it is announced by the specilaized authorities.

\section{REFERENCES}

Abdul Hussain, A. (2014). The Reality of Using Environmental Accounting in Industrial Establishments: An Empirical Study on a Number of Industrial Establishments in Iraq. Al-Ghari Journal of Economic and Administrative Sciences, 10th Year, vol. 8, no. 31, pp. 292.

Bae, A., K. and Kim, J., D., (2017). Analysis of Environmental Accounting and Reporting Practices of Listed Banking Companies in Bangladesh, Sustainability, MDPI Journal, vol. 9, no. 1717

Darwish, A. (2009). The Effect of Accounting Disclosure on the Environmental Performance of Jordanian Industrial Companies on the Rationalization of Decisions and the Quality of Financial Reports- Moral Entrance. Egyptian Journal of Business Studies, vol. 31, no. 1, pp. 10

Eljayash, K. M. (2015). Documentation of Environmental Disclosure Practices in the Oil Companies in the Countries of the Arab Spring Some Evidences from Egypt, Libya and Tunisia. Journal of Economics, Business and Management, vol. 3, no. 10, pp. 954

Environmental Protection Law No. 52 of (2006). Published on page 37-40 of the Official Gazette No. 4787 dated 16/10/2006, replaced the Environmental Protection Act No. 1 of 2003.

Jariya I. (2015). Environmental Disclosures in Annual Reports of Sri Lankan Corporate: A Content Analysis. Journal of Emerging Trends in Economics and Management Sciences (JETEMS), vol. 6, no. 8, pp. 350-357.

Mazahrih, B. J., Katrib, D. I., Rfaah, T. M. (2016). Environmental Disclosure: The Case of Jordanian Chemical Industry. Journal of Accounting, Finance and Economics, vol. 6, no. 1, pp. 88.

Md, H., U., Md, M., H. And Yakub, K., M., (2014). Environmental Disclosure Practices in Annual Report of the Listed Textile Industries in Bangladesh. Global Journal of Management and Business Research: D Accounting and Auditing, vol. 14, no. 1.

Al-Rashed, W. (2013). Measuring Environmental Pollution and its Disclosure. Arab Journal of Accounting, vol. 16, no. 1, pp. 11.

Saleh, M. (2015). The Role of the Environmental Awareness in the Application of Environmental Accounting Disclosure in the Jordanian Industrial Public Contribution Companies and its Impact on Investor's Decisions in the Amman Financial Market. PhD Thesis, Al- Jinan University, Tripoli, Lebanon, 2-89.

Suttipun A. and Stanton B. (2012). Determinants of Environmental Disclosure in Thai Corporate Annual Reports. International Journal of Accounting and Financial Reporting, vol. 2, no. 1, pp. 99-115.

Uzzaman, A. H. \& Kowsar, A. S. (2014). Corporate Environmental Reporting (CER) Practices: Evidence from Selected Non-Financial Companies in Bangladesh. International Journal of Business and General Management (IJBGM), vol. 3, no. 1, pp. 1-8.

Welbeck, Emerald Edem, Owusu, Godfred Matthew Yaw, Bekoe, Rita Amoah and Kusi, J. (2017). Determinants of environmental disclosures of listed firms in Ghana. International Journal of Corporate Social Responsibility, vol. 2, no. 11.

Yusoff H., Othman R. and Yatim N. (2013). Environmental Reporting Practices in Malaysia and Australia. The Journal of Applied Business Research, vol. 29, no. 6, pp. 1717 